\title{
Drying temperatures on the functional properties of purple-fleshed sweet potato
}

\section{Herbert Gama Vidal ${ }^{2}$ Leticia Figueiredo de Araujo ${ }^{1}$ José Lucena Barbosa Junior $^{1^{*}}$ (D)}

\begin{abstract}
'Departamento de Tecnologia de alimentos, Instituto de Tecnologia, Universidade Federal Rural do Rio de Janeiro (UFRRJ), 23890-000, Seropédica, RJ, Brasil. E-mail: lucenadta@gmail.com. "Corresponding author.

${ }^{2}$ Programa de Pós-graduação em Ciência e Tecnologia de Alimentos, Universidade Federal Rural do Rio Janeiro (UFRRJ), Seropédica, RJ, Brasil.
\end{abstract}

ABSTRACT: Purple-fleshed sweet potatoes are rich in phenolic compounds, such as anthocyanins, and also exhibit hypoglycemic properties. Anthocyanins are natural antioxidants with the capacity to inhibit or delay injuries caused by free radicals. Drying is one of the most commonly used vegetable preservation methods; although, it has parameters that affect the sensory and physicochemical properties of the final product. The present study assessed the impact of drying temperatures $\left(40,50\right.$, and $60^{\circ} \mathrm{C}$ ) on the purple-fleshed sweet potato. Cut, unpeeled potato slices of $4 \mathrm{~cm}$ in diameter and $3 \mathrm{~mm}$ in thickness were dried in an oven with hot air circulation. The effect of the different temperatures on the antioxidant capacity, phenolic compound content, and total and monomeric quantities of anthocyanins in purple sweet potato were measured, and a mathematical model describing the drying kinetics was determined. According to the results observed, the process at $40{ }^{\circ} \mathrm{C}$ better preserved the phenolic compounds; however, drying at $50^{\circ} \mathrm{C}$ was more efficient for conserving the antioxidant capacity measured by the $H+$ capture method performed by DDPH, and for the total and monomeric quantities of anthocyanins. The mathematical models that best described the kinetic curves were those of Henderson and Pabis, and Page.

Key words: anthocyanins, bioactive compounds, Henderson and Pabis, Page model, drying kinetics, Ipomoea potatoes.

Efeito das temperaturas de secagem nas propriedades funcionais da batata doce de polpa roxa

RESUMO: A batata doce roxa de polpa roxa é rica em compostos fenólicos, como as antocianinas além de possuir também propriedades hipoglicêmicas. As antocianinas são antioxidantes naturais capazes de inibir ou retardar lesões causadas por radicais livres. Um dos métodos de conservação de vegetais mais utilizados é a secagem. Mesmo sendo um método de execução simples, possui parâmetros de processo que interferem amplamente em termos sensoriais e nas propriedades fisico-químicas do produto final. O presente trabalho teve por objetivo avaliar o impacto de três temperaturas de secagem $\left(40,50\right.$ e $\left.60^{\circ} \mathrm{C}\right)$, em rodelas de batata doce roxa de polpa roxa com casca, com diâmetro de $4 \mathrm{~cm}$ e espessura de $3 \mathrm{~mm}$, em desidratador com circulação de ar quente sobre a capacidade antioxidante, teor de compostos fenólicos, antocianinas totais e monoméricas, além de determinar um modelo matemático que pudesse descrever as cinéticas de secagem. De acordo com os resultados obtidos a secagem a $40^{\circ} \mathrm{C}$ se mostrou mais conveniente em termos de compostos fenólicos, porém a secagem a $50{ }^{\circ} \mathrm{C}$ se mostrou mais eficiente para o resultado de capacidade antioxidante pelo método de captura de $\mathrm{H}^{+}$realizado por DPPH e para antocianinas totais e monoméricas. Os modelos matemáticos que descreveram melhor as curvas de cinética foram o modelos de Henderson e Pabis e o de Page.

Palavras-chave: antocianinas, compostos bioativos, Henderson e Pabis, Page, cinética de secagem, Ipomoea batatas.

\section{INTRODUCTION}

Sweet potato (Ipomoea batatas L.) is a plant originating in America that is classified by its format, size, and skin and pulp color, among other factors. It is an edible tuberous root with approximately 50 genera and more than 1000 species (NASCIMENTO, 2017). Its cultivation is widespread throughout Brazil due to its production capacity in poor soils, low incidence of pests and limiting diseases, and reduced management requirements. Given thevast overall knowledge of this vegetable, it is widely used in domestic cooking or as a raw material for industrial processes (ROESLER et al., 2008).

The presence of polyphenols, anthocyanins, $\beta$-carotene, vitamins, and fibers promoted sweet potato functionality and nutritional value (TOYAMA et al., 2006). Among the numerous varieties of skin and pulp colors of sweet potatoes, the purple pulp is highlighted for its bioactive properties due to phenolic compounds such as anthocyanins, and also for its hypoglycemic capacity (JIANTENG XU et al., 2015).

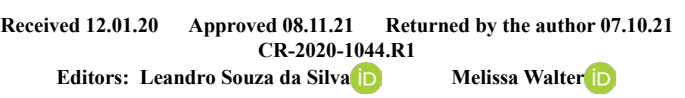


Phenolic substances are known for their antioxidant capacity, providing functionality to various foods and inhibiting or delaying injuries caused by free radicals. These are molecules with one or more unpaired electrons that quickly react with different cellular targets, causing damage associated with degenerative disease and aging processes. Anthocyanins are phenolic compounds that are abundant in purplefleshed sweet potato (PSP) (VIZZOTTO et al., 2017).

Anthocyanins are water-soluble pigments that belong to the group of flavonoids responsible for a wide variety of colors in fruits, ranging from redorange to purple. Their primary function is to protect the plant against ultraviolet (UV) rays and prevent the formation of free radicals, and the main anthocyanins reported in purple sweet potatoes are the acylated forms of cyanidin and peonidin. The acylation pattern of different phenolic acids makes PSP anthocyanins unique and offers stabilization advantages over $\mathrm{pH}$, heat, and light resistance (OLIVEIRA et al., 2019).

Temperature is an important factor in the stability of anthocyanins since degradation starts at temperatures above $25{ }^{\circ} \mathrm{C}$, and it advances as the $\mathrm{pH}$ of the medium increases. However, some studies have shown, such as those conducted by SAPERS et al. (1981) and CHIGURUPATI et al. (2002), that the stability of anthocyanins regarding temperature is positively correlated to the degree of acylation (LOPES et al., 2007). Additionally, purple sweet potato anthocyanins are reported primarily in acylated form with phenolic acids, keeping them stabilized under $\mathrm{pH}$ changes, high temperatures, and light variations (JIANTENG XU et al., 2015).

Due to their perishability, the primary use of roots and tubers is in cooking or as a raw material for obtaining sweets, flour, flakes, and starch (ROESLER et al., 2008). Drying is a widely used conservation method for obtaining flours, and despite being straight forward it has process parameters that interfere with the sensory attributes and physicochemical properties of the final product (ALONSO \& PARK, 2005).

The analysis of drying kinetics provides information about the mass transfer behavior between purple pulp sweet potato slices and the drying agent (hot air). It is fundamental to determine the drying time and the final relative humidity of the flour to be produced for dryer design and simulations.

Although, studies exist on the evaluation of different drying methods on purple sweet potato in relation to bioactive activity, research on the effect of convective drying conditions on the quality and quantity of bioactive compounds present in purple-fleshed sweet potatohas not been identified. Thus, this study evaluated the impact of different drying temperatures in a dehydrator with hot air circulation on the antioxidant capacity, phenolic compound content, and total and monomeric anthocyanins in purple-fleshed sweet potato, as well as to propose a mathematical model that could describe the drying kinetics involved.

\section{MATERIALS AND METHODS}

The sweet potato (Ipomoea batatasL.) used in this study had purple skin and purple pulp (PSP) and was obtained through the Integrated Agroecological Production System -SIPA (Fazendinha Agroecológica) located in Seropédica, Rio de Janeiro -RJ $\left(22^{\circ} 48^{\prime} 00^{\prime \prime} \mathrm{S}\right.$ and $43^{\circ} 41^{\prime} 00^{\prime \prime} \mathrm{W}$ ).

The PSP samples used in the drying process followed the preparation flowchart shown in figure 1 .

\section{Physicochemical analysis}

The moisture content of the raw material was determined by dry weight at $105^{\circ} \mathrm{C}$ in an oven following the method $012 / \mathrm{IV}$ of the Adolfo Lutz

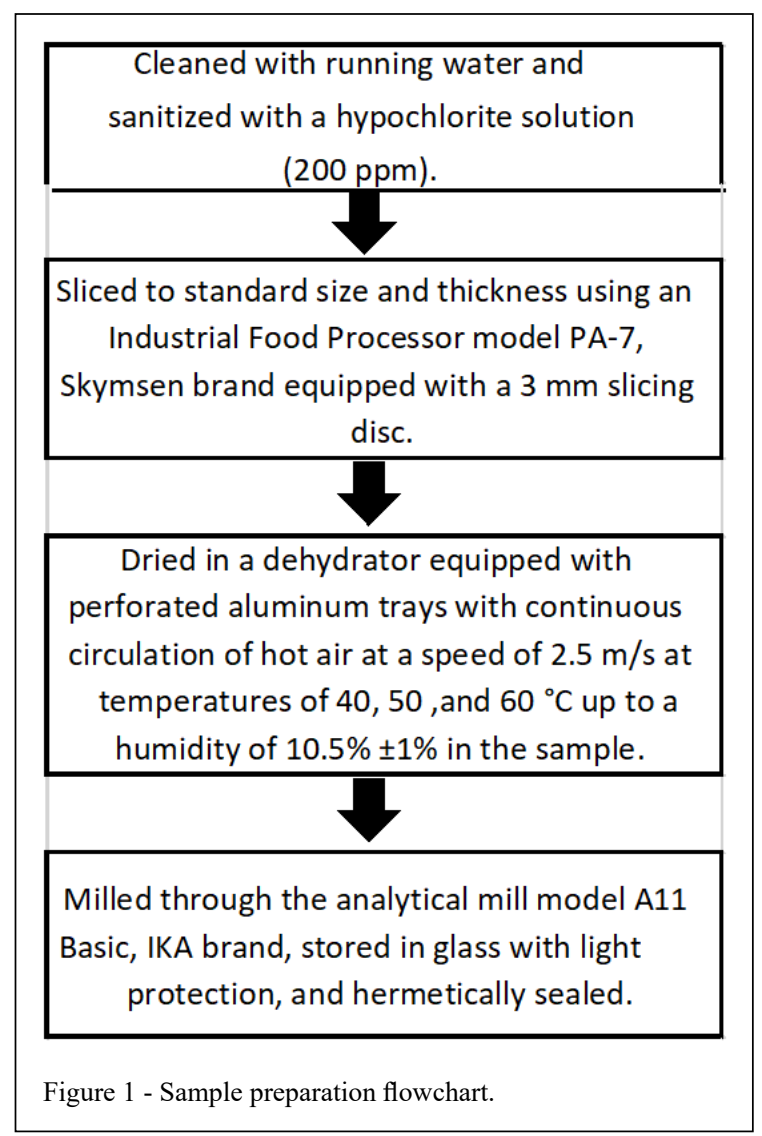


Institute (IAL, 2005), performed in triplicate using an initial mass of approximately $10 \mathrm{~g}$ for each sample.

The extract preparation procedure for the analyses of antioxidant capacity, phenolic compounds content, and total and monomeric anthocyanins, was performed according to RUFINO et al. (2010), with minor modifications. One gram of sample was weighed and transferred into an Erlenmeyer flask along with $25 \mathrm{~mL}$ of solvent (acetone: alcohol: water, 40:40:20 $\mathrm{v} / \mathrm{v} / \mathrm{v}$ ), and stirred at $3500 \mathrm{pm}$, at room temperature for $1 \mathrm{~h}$, in the dark. After extraction, the extract was filtered through a no. 3 sintered funnel with the aid of a vacuum pump (SOLAB, Model SL-60). The residue retained on the filter was then re-extracted and washed with $5 \mathrm{~mL}$ of solvent under the same conditions. The filtrates were placed in a volumetric flask $(100 \mathrm{~mL})$ in the dark and used for physicochemical analyses.

The total phenolic compounds in the studied flour fractions were obtained according to SWAIN \&HILLIS (1959), with modifications. One milliliter of extract, $10 \mathrm{~mL}$ of distilled water, $1 \mathrm{~mL}$ of Folin Ciocalteau $0.25 \mathrm{~N}$ reagent, and $1.5 \mathrm{~mL}$ of $10 \%$ $\mathrm{Na}_{2} \mathrm{CO}_{3}$ were added, followed by homogenization. The solution was stored at room temperature in the dark for $2 \mathrm{~h}$, and the absorbance was measured at $725 \mathrm{~nm}$ using a spectrophotometer. Results were expressed as the mg equivalent of gallic acid per gram of dry sample (mg GAE. $\mathrm{g}^{-1}$ of the dry sample).

Antioxidant capacity was determined using the DPPH method according to the procedure described by RUFINO et al. (2010), with minor modifications. Extracts $(150 \mu \mathrm{L})$ were reacted with $2.85 \mathrm{~mL}$ of a methanolic solution of DPPH $(0.06 \mathrm{mM})$ for $1 \mathrm{~h}$ in the dark. The absorbance was then read using a spectrophotometer (Spectrophotometer Model NOVA $2000 \mathrm{UV}$ ) at a wavelength of $517 \mathrm{~nm}$. Trolox was used as a reference for the construction of the calibration curve, and the results were expressed in $\mu \mathrm{g}$ of Trolox equivalent per gram of sample.

Phosphomolybdenum analysis was performed using spectrophotometry, whereby $0.3 \mathrm{~mL}$ of extract was added to a reagent mixture $(3 \mathrm{~mL})$ containing $0.6 \mathrm{M}$ sulfuric acid, $28 \mathrm{mM}$ sodium phosphate, and 4 $\mathrm{mM}$ ammonium molybdate. After $90 \mathrm{~min}$ of incubation at $95{ }^{\circ} \mathrm{C}$, the absorbance of the mixture was read at 695 $\mathrm{nm}$; the blank consisted of $0.3 \mathrm{~mL}$ ethanol with $3 \mathrm{~mL}$ of the reagent mixture. Results are expressed in millimoles of Trolox per gram of sample.

The quantification of total and monomeric anthocyanins was performed using the differential $\mathrm{pH}$ method proposed by GIUSTI \& WROLSTAD (2001), with absorbances measured at $\lambda 510$ and $\lambda 700 \mathrm{~nm}$ for $\mathrm{pH} 1.0$ and 4.5, respectively in an SP 22 visible UV spectrophotometer.Results were expressed in cyanidin equivalent milligrams - three glycosides per kilogram of purple sweet potato dry mass $\left(\mathrm{mg}_{\mathrm{eq}} \cdot \mathrm{C}_{3} \mathrm{G} / \mathrm{kg}\right)$.

\section{Obtaining data for the kinetic curve}

The drying process was performed in a dehydrator with hot air circulation at a speed of 2.5 $\mathrm{m} / \mathrm{s}$, equipped with a digital temperature controller and perforated aluminum trays. Continuous repetitive weighing of the samples was conducted until they reached a constant weight, as shown in table 1 .

The drying curves were obtained by converting the data relatingto water loss into the dimensionless water content ratio (Y) parameter, using the following formula (Equation 1):

$Y=\frac{X_{\text {bus }}-X_{e}}{X_{\text {businitial }}-X_{e}}$

Xbus = water content (dry basis);

Xbus initial = initial water content (dry basis); and $\mathrm{Xe}=$ water content in the equilibrium (dry basis).

The experimental data for the drying of the purple pulp of sweet potato (Table 1) were fitted to four mathematical models (Equations 2-5) that are frequently used to represent the kinetics of agricultural products, and are presented in table 2 to predict the drying time required to achieve a specific moisture content in the purple sweet potato flour.

The effective diffusivity (Def) of the water inside the product was determined by assuming the approximation of the purple pulp sweet potato slices to the shape of a flat plate using the following information (CRANK, 1975):

- uniform initial moisture $\mathrm{X}(\mathrm{z}, \mathrm{t})=\mathrm{X}(\mathrm{z}, 0)=\mathrm{X} 0$;

- maximum humidity in center $\partial X /\left.\partial z\right|_{z=0}=0$, and

- constant humidity on surface $X(z, t)=X(1, t)=X e q$. Thus

$Y=\frac{8}{\pi^{2}} \sum_{i=0}^{\infty} \frac{1}{(2 i+1)^{2}} \exp \left(-(2 i+1)^{2} \pi^{2} D_{e f} \frac{t}{4 L^{2}}\right)$

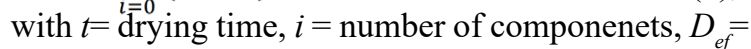
effective diffusivity,

$2 L=$ thickness of the flat sample, and $Y=$ the dimensionless parameter.

A nonlinear regression analysis was performed to adjust the mathematical models to the experimental data using the quasi-Newton method, using the computer program STATISTICA $7.0^{\circledR}$. The parameter values were estimated as a function of the sample's independent variable, air drying temperature, and equilibrium water content.

\section{Statistical analysis}

The statistical values of the coefficient of determination $\left(\mathrm{R}^{2}\right)$ and root mean square error (RMSE)

Ciência Rural, v.52, n.6, 2022. 
Table 1 - Drying data in a dehydrator with forced hot air circulation.

\begin{tabular}{lllllll}
\hline & & & & \\
\hline
\end{tabular}

were used as the first criteria for evaluating the best mathematical model. However, to better assess the non-linear mathematical models, the mean relative error (E) was employed, according to Equation 7:

$E(\%)=\frac{100}{N} \sum_{i}^{N}\left|\frac{Y-\bar{Y}}{Y}\right|$

where:

$Y=$ experimental value, $\bar{Y}=$ predicted model values, and $N=$ experimental data points.

The development of the model allows the predictability of drying time $\times$ the relative humidity of the sample that is expected for dehydrators with continuous hot air circulation.

The statistical analysis of the drying points was performed using the chi-square test to verify the existence of a significant difference $(\mathrm{P}<0.05)$ between the point values, using Minitab 19 Software (Pennsylvania, USA, 2019). Means were compared using Tukey's test $(\mathrm{P} \leq 0.05)$.

\section{RESULTS AND DISCUSSION}

The samples after dryingat 40, 50, and $60{ }^{\circ} \mathrm{C}$ are presented in table 1 , which shows that

Table 2 - Mathematical models applied to the drying of purple-fleshed sweet potato.

\begin{tabular}{|c|c|c|c|}
\hline \multicolumn{4}{|l|}{ Models } \\
\hline Fick - with 6 terms & $Y=\frac{8}{\pi^{2}} \sum_{i=0}^{\infty} \frac{1}{(2 i+1)^{2}} \exp \left(-(2 i+1)^{2} \pi^{2} D_{\text {ef }} \frac{t}{4 L^{2}}\right)$ & (BROOKER et al., 1992) & (6) \\
\hline Henderson; Pabis & $Y=a \cdot \exp (-k \cdot t)$ & (HENDERSON\& PABIS, 1961) & (7) \\
\hline Page & $Y=\exp \left(-k \cdot t^{n}\right)$ & (PAGE, 1949) & (8) \\
\hline Peleg & $Y=1-\frac{t}{(a+b \cdot t)}$ & (PELEG, 1988) & (9) \\
\hline
\end{tabular}

Y- water content ratio (dimensionless); t- drying time (min); L-thickness of the flat sample;

k- drying constants; a,b,n- model coefficients; Def - effective diffusivity $\left(\mathrm{m}^{2} / \mathrm{s}\right)$. 
the dehydration stability, that is, the non-significant difference between the measured points, is reached earlier at50 and $60{ }^{\circ} \mathrm{C}$ when compared to the results at $40^{\circ} \mathrm{C}$. According to PARK et al. (2001), the evaporation of water contained in a solid is governed by two phenomena: heat transfer and mass transfer. Mass transfer is a function of the physical nature of the solid in terms of its temperature and moisture content, and heat is governed by parameters such as temperature, air humidity, airflow, air direction, and the exposed area of the solid. In this study, the only parameter that changed between the analyses was the drying air temperature; that is, higher temperatures tended to lead to earlier stabilization when compared to lower temperatures.

However, when analyzing the endpoints of the analysis (1440 and $1500 \mathrm{~min}$ ), a lower humidity was observed in the samples at $50{ }^{\circ} \mathrm{C}$ and $40{ }^{\circ} \mathrm{C}$ compared to the dry sample at a temperature of $60^{\circ} \mathrm{C}$. This result relates to the dried crust formation on the surface of samples that hada high sugar content and were dried at high temperatures, whichcreates challenges in the removal of non-free water and; consequently, dehydration of the sample (PARK et al., 2007).

Table 3 shows the coefficient values of the four mathematical models analyzed and the statistical values of the determination coefficients $\left(\mathrm{R}^{2}\right)$, adjusted determination coefficients $\left(\mathrm{R}_{\text {adj }}^{2}\right)$ of the root mean square error (RMSE), and mean relative error $(E)$.

Based on the findings of GONELI et al. (2009) and SILVA et al. (2015), the magnitude of the drying constant $(\mathrm{k})$ in our study has a direct correlation with the drying air temperature.
In all treatments, the mathematical models adjusted to the experimental data presented coefficients of determination $\left(\mathrm{R}^{2}\right)$ above $97.81 \%$ and RMSE values below 0.039 . Other drying studies obtained similar results, showing high values for $\mathrm{R}^{2}$. SILVA et al. (2015) obtained $\mathrm{R}^{2}$ values above $97 \%$ for dried achachairu pulp, and COSTA et al. (2018) acquired an $\mathrm{R}^{2}$ greater than 99\% for the kinetics of ripe banana using the Henderson and Pabis, and Page models. For the drying of pão/sapo green banana, TAVONE et al. (2020) obtained $\mathrm{R}^{2}$ values greater than $99 \%$ using the Page model.

Although, the four studied models demonstrated an adequate representation in the description of the drying kinetics of purple-fleshed sweet potatoes, according to MADAMBA et al. (1996), $\mathrm{R}^{2}$ greater than $95 \%$ is the minimum value required to obtain a good reproduction of the models. Therefore, the Henderson and Pabis, and Page models were the best fit because they presented greater $\mathrm{R}^{2}$ values and the lowest RMSE (Table 2).

Fick's second law describes the dynamic behavior of the drying process during the period of decreasing moisture over time, since effective diffusion (Def) is the primary mass transfer mechanism (HENRÍQUEZ et al., 2014). The increase in temperature directly affected the effective diffusion of the sample; as shown in table 2 , there was an increase in this constant compared to the temperatures of 40 and $60{ }^{\circ} \mathrm{C}$.

Figure 2 shows the drying kinetics estimated by Fick(6-term diffusive models), Henderson and Pabis, Page, and Peleg. The best

Table 3 - Statistical parameters and drying constant of the applied mathematical models.

\begin{tabular}{|c|c|c|c|c|c|c|c|c|c|c|}
\hline \multirow[t]{2}{*}{ Model } & \multirow[t]{2}{*}{$\mathrm{T}\left({ }^{\circ} \mathrm{C}\right)$} & \multicolumn{5}{|c|}{ 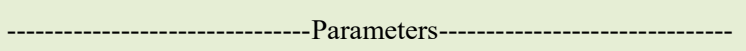 } & \multirow[t]{2}{*}{$\mathrm{R}^{2}$} & \multirow[t]{2}{*}{$\mathrm{R}^{2}$ (adj) } & \multirow[t]{2}{*}{ RMSE } & \multirow[t]{2}{*}{$\mathrm{E}(\%)$} \\
\hline & & Def & $\mathrm{k}$ & $\mathrm{n}$ & $\mathrm{a}$ & $\mathrm{b}$ & & & & \\
\hline \multirow[t]{3}{*}{ Fick } & $40^{\circ} \mathrm{C}$ & $3.1675 \mathrm{E}-10$ & - & - & - & - & 0.9781 & 0.6781 & 0.0388 & 25.0980 \\
\hline & $50^{\circ} \mathrm{C}$ & $4.5273 \mathrm{E}-10$ & - & - & - & - & 0.9792 & 0.6792 & 0.0300 & 27.4081 \\
\hline & $60^{\circ} \mathrm{C}$ & $5.5245 \mathrm{E}-10$ & - & - & - & - & 0.9792 & 0.6792 & 0.0231 & 15.5659 \\
\hline \multirow{3}{*}{$\begin{array}{l}\text { Henderson } \\
\& \text { Pabis }\end{array}$} & $40^{\circ} \mathrm{C}$ & - & 0.0070 & - & 1.0376 & - & 0.9976 & 0.9143 & 0.0131 & 9.1773 \\
\hline & $50^{\circ} \mathrm{C}$ & - & 0.0100 & - & 1.0463 & - & 0.9972 & 0.9138 & 0.0130 & 10.5615 \\
\hline & $60^{\circ} \mathrm{C}$ & - & 0.0128 & - & 1.0167 & - & 0.9990 & 0.9157 & 0.0280 & 19.2568 \\
\hline \multirow[t]{3}{*}{ Page } & $40^{\circ} \mathrm{C}$ & - & 0.0026 & 1.1859 & - & - & 0.9996 & 0.9163 & 0.0048 & 2.7007 \\
\hline & $50^{\circ} \mathrm{C}$ & - & 0.0031 & 1.2389 & - & - & 0.9997 & 0.9164 & 0.0087 & 6.7135 \\
\hline & $60^{\circ} \mathrm{C}$ & - & 0.0090 & 1.0752 & - & - & 0.9993 & 0.9159 & 0.0059 & 6.9479 \\
\hline \multirow[t]{3}{*}{ Peleg } & $40^{\circ} \mathrm{C}$ & - & - & - & 110.7582 & 0.8437 & 0.9824 & 0.8991 & 0.0383 & 39.2784 \\
\hline & $50^{\circ} \mathrm{C}$ & - & - & - & 75.1932 & 0.8635 & 0.9793 & 0.8960 & 0.0371 & 44.9725 \\
\hline & $60^{\circ} \mathrm{C}$ & - & - & - & 53.1257 & 0.8963 & 0.9861 & 0.9027 & 0.0280 & 32.7852 \\
\hline
\end{tabular}

The means of each variable were compared by tukey's test $(\mathrm{P}<0.05)$.

Ciência Rural, v.52, n.6, 2022. 
fits were determined by the Henderson and Pabis and Page models because of their correspondence between experimental and estimated values.

The most significant amount of phenolic compounds was obtained from the dry flour at $40{ }^{\circ} \mathrm{C}$. The drying process facilitated their extraction; however, in general, a higher drying temperature corresponds to a greater degradation of the phenolic compounds, which did not differ from the values obtained for the purple sweet potato with purple pulp. TANG et al. (2015) obtained similar results when they studied the behavior of phenolic compounds in purple sweet potato under different thermal processes (traditional cooking for $30 \mathrm{~min}$, steam cooking for $30 \mathrm{~min}$, and drying in a traditional oven at $230{ }^{\circ} \mathrm{C}$ for $30 \mathrm{~min}$ ). They obtained the highest content with traditional cooking, which is the least severe method in terms of temperature. YANG et al. (2010) demonstrated that the total phenolic compounds of purple sweet potato increased in all drying processes applied (drying with hot air, microwave, and lyophilization) when compared to the content of the fresh samples. This is due to cell disruption during thermal processing, which allows for a greater extraction of compounds.
The results of the phenolic compounds obtained in the present study $(18.24-32.02 \mathrm{mg}$ EAG/100 g dry sample), corroborated those reported by other authors in studies with purple sweet potatoes. TANG et al. (2015) reported results ranging from 11.43 to $24.90 \mathrm{mg} \mathrm{GAE} / 100 \mathrm{~g}$ dry sample, and AHMED et al. (2010) showed a range of 4.29 to $8.33 \mathrm{mg} \mathrm{GAE} / 100 \mathrm{~g}$ dry sample in purple sweet potato flour samples.

The drying process increased the antioxidant capacity of the studied samples, as shown in table 4, and the highest index was obtained for the flour dried at $50{ }^{\circ} \mathrm{C}$ using the free radical capture method by DDPH. For the flour dried at $60{ }^{\circ} \mathrm{C}$, increased values were found in the total antioxidant capacity method performed by phosphomolybdenum analysis. This difference in the analysis is due to the anthocyanin content in the samples at 50 and $60{ }^{\circ} \mathrm{C}$, where the degradation of anthocyanins during drying at higher temperatures results in a decrease in the capacity to capture free radicals (LOPES et al., 2007).

We observed that the drying temperature of the flour obtained in this study directly influenced the total anthocyanin content. The flour dried at $50{ }^{\circ} \mathrm{C}$ had

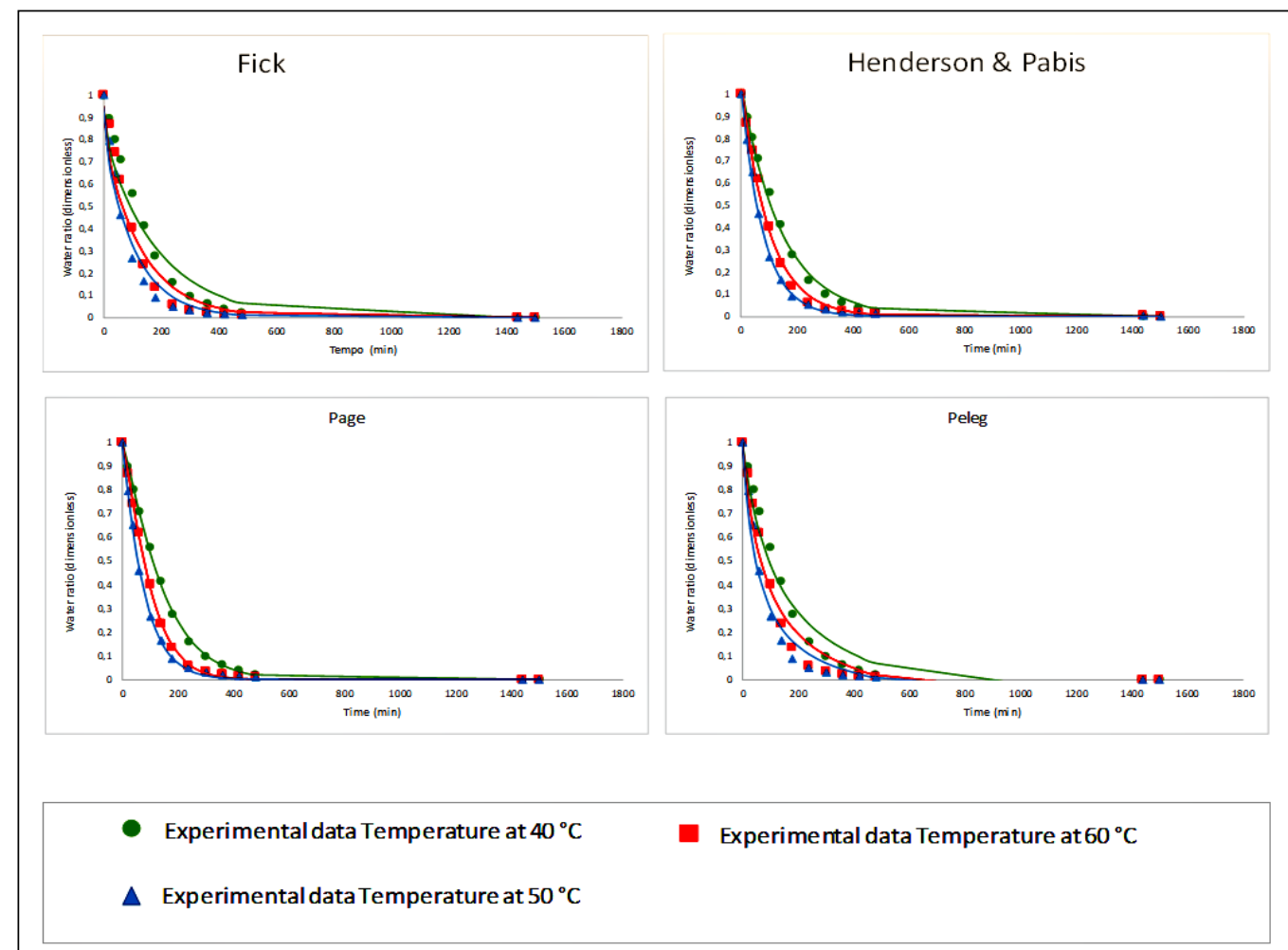

Figure 2 - Kinetic models and experimental data of purple pulp sweet potato drying. 
Table 4 - Results of analysesof purple pulp sweet potato flour.

\begin{tabular}{|c|c|c|c|c|c|}
\hline Extract & $\begin{array}{c}\text { Phenolic } \\
\text { Compounds }^{\mathrm{a}}\end{array}$ & $\mathrm{DPPH}^{\mathrm{b}}$ & Phosphomolybdenum ${ }^{c}$ & Total Anthocyanins ${ }^{\mathrm{d}}$ & $\begin{array}{c}\text { Monomeric } \\
\text { Anthocyanins }^{\mathrm{d}}\end{array}$ \\
\hline In Natura & $11.86 \pm 0.33^{\mathrm{f}}$ & $29.81 \pm 3.75^{\mathrm{f}}$ & - & $24.86 \pm 0.78^{f}$ & $5.07 \pm 0.43^{\mathrm{f}}$ \\
\hline Flour $40{ }^{\circ} \mathrm{C}$ & $32.02 \pm 0.52^{\mathrm{g}}$ & $40.97 \pm 2.66^{\mathrm{g}}$ & $240.39 \pm 50.44^{\mathrm{g}}$ & $38.19 \pm 1.02^{\mathrm{g}}$ & $7.67 \pm 1.05^{\mathrm{g}}$ \\
\hline Flour $50{ }^{\circ} \mathrm{C}$ & $25.94 \pm 0.35^{\mathrm{h}}$ & $56.47 \pm 3.08^{\mathrm{h}}$ & $629.52 \pm 25.82^{h}$ & $72.07 \pm 2.69^{h}$ & $14.96 \pm 2.46^{\mathrm{h}}$ \\
\hline Flour $60^{\circ} \mathrm{C}$ & $18.24 \pm 0.21^{\mathrm{i}}$ & $32.03 \pm 3.57^{\mathrm{f}}$ & $929.31 \pm 49.15^{\mathrm{i}}$ & $37.09 \pm 0.76^{\mathrm{g}}$ & $7.36 \pm 0.99^{\mathrm{g}}$ \\
\hline
\end{tabular}

${ }^{\text {a }}$ Expressed in mg gallic acid/100g sample.

${ }^{b}$ Expressed in $\mathrm{mg}$ of Trolox equivalent/g of sample.

${ }^{\mathrm{c}}$ Expressed in mmol Trolox/g sample.

${ }^{\mathrm{d}}$ Expressed in mg cyanidin-3-glucoside equivalent/100g dry weight sample.

Means followed by the same letter do not differ statistically from each other, according to Tukey's test $(\mathrm{P}<0.05)$.

the highest content $(72.07 \mathrm{mg} / 100 \mathrm{~g}$ of dry sample), followed by that at $40{ }^{\circ} \mathrm{C}(38.19 \mathrm{mg} / 100 \mathrm{~g}$ of dry sample) and $60^{\circ} \mathrm{C}(37.09 \mathrm{mg} / 100 \mathrm{~g}$ of the dry sample). This parabolic behavior in anthocyanin content at different temperatures has two explanations. First, because drying at $40{ }^{\circ} \mathrm{C}$ has a longer duration (at least $60 \%$ longer than other temperatures), degradation of anthocyanins occurs during the drying process. Second, as OLIVEIRA et al. (2015) stated, there is a deleterious effect on anthocyanins at higher temperatures, as shown in the results of the present study.
When comparing the total anthocyanins of the samples in this study with the data obtained in the literature from different purple sweet potato varieties, it can be observed that the three flours with content between $37.09-72.07 \mathrm{mg} / 100 \mathrm{~g}$ of dry sample were similar to those found by other researchers. TEOW et al. (2007) reported total anthocyanin content in 19 sweet potato genotypes, ranging from 1.7 to $53.1 \mathrm{mg} / 100 \mathrm{~g}$ of fresh sample. table 5 shows that the purple-fleshed sweet potato used here presents levels of total anthocyanins similar to other studies

Table 5 - Comparison of total anthocyanin content in purple sweet potato studies.

\begin{tabular}{lccc}
\hline Variety name & Anthocyanins $^{\mathrm{a}}$ & Method & References \\
\hline Stokes Purple & $328^{\mathrm{b}}$ & & \\
NC 415 & $178^{\mathrm{b}}$ & pH differential & TRUONGet al. (2010) \\
Okinawa & $65^{\mathrm{b}}$ & & KIMet al. (2012) \\
Shinzami & 1342 & HPLC & ZHU et al. (2010) \\
\hline 12 Variedades da China Central & $78-695$ & HPLC & RODRIGUEZ-SAONA et al. (1998) \\
NDOP5847-1 & 175 & pH differential & JIANTENG XUet al. (2015) \\
\hline P40 & 1390 & HPLC & VIZZOTTOet al. (2017) \\
ILS 16 & $1112^{\mathrm{b}}$ & pH differential & \\
ILS 56 & $1072^{\mathrm{b}}$ & & PILON et al. (2020) \\
ILS 71 & $361^{\mathrm{b}}$ & & \\
CNPH 0005 & 88,6 & pH differential & \\
CNPH 0080 & 60,6 & & \\
CNPH 1261 & 57 & & \\
CNPH 1399 & 193,8 & & \\
CNPH 1402 & 56,2 & & \\
CNPH 1405 & 200 & & \\
\hline
\end{tabular}

${ }^{a}$ in $\mathrm{mg} / 100 \mathrm{~g}$ dry sample. $\mathrm{b}$ values converted to dry basis using $77 \%$ moisture as indicated in the USDA Food and Nutrient Database for Dietary Studies. 
but in relatively smaller amounts when compared to some species, particularly Asian varieties. According to ISHIGURO et al. (2017), factors such as relative humidity and temperature influence the concentration of anthocyanins during the production of purple sweet potato.

Regarding monomeric anthocyanins, the results follow the same pattern as total anthocyanins, with the highest content found in the $50{ }^{\circ} \mathrm{C}$ sample (14.95 mg/100 $\mathrm{g}$ of dry sample), followed by 40 ${ }^{\circ} \mathrm{C}\left(7.67 \mathrm{mg} / 100 \mathrm{~g}\right.$ of dry sample) and $60{ }^{\circ} \mathrm{C}(7.36$ $\mathrm{mg} / 100 \mathrm{~g}$ dry sample).

\section{CONCLUSION}

The present study demonstrated that it is possible to obtain purple sweet potato flour with purple pulp that meets the moisture specifications (less than 13\%, according to Resolution No. 344, of December 13, 2002) with shorter drying times (140 to $300 \mathrm{~min}$ ) when using a dehydrator with a continuous circulation of hot air.

The best mathematical model that described the drying kinetics at all temperatures was the Page model, followed by the Henderson and Pabis model.

The physicochemical properties varied according to the temperature of the air used for drying in an oven with forced ventilation. The total phenolic compounds decreased as the drying temperature increased, but with higher content than the fresh sample. However, the antioxidant potential increased up to a drying temperature of $50{ }^{\circ} \mathrm{C}$ and decreased at a temperature of $60{ }^{\circ} \mathrm{C}$. The same behavior was observed in the analysis of total and monomeric anthocyanins; the values increased until the drying temperature reached $50{ }^{\circ} \mathrm{C}$ and then decreased at 60 ${ }^{\circ} \mathrm{C}$. The most suitable temperature for drying this purple sweet potato with purple pulp was $50^{\circ} \mathrm{C}$, with forced ventilation.

\section{DECLARATION OF CONFLICT OF INTEREST}

The authors declare no conflict of interest. Funding sponsors had no role in the design of the study; the collection, analyses, or interpretation of data; the writing of the manuscript; or the decision to publish the results.

\section{AUTHORS' CONTRIBUTION}

All authors contributed equally to the conception and writing of this manuscript. All authors critically revised the manuscript and approved the final version.

\section{ACKNOWLEDGEMENTS}

We would like to thank the unrestricted support of the entire team of the Programa de Pós-Graduação em Ciência e Tecnologia de Alimentos (PPGCTA) at the Universidade Federal Rural do Rio de Janeiro (UFRRJ). And was financed in part by the Coordenação de Aperfeiçoamento de Pessoal de Nível Superior (CAPES), Brasil - Finance code 001.

\section{REFERENCES}

AHMED, Met al. Peeling, drying temperatures, and sulphitetreatment affect physicochemical properties and nutritional quality of sweet potato flour. Food Chemistry, 121, 112-118, 2010. Available from: <https://www.academia.edu/6546128>. doi: 10.1016/j.foodchem.2009.12.015.

ALONSO, L. F. T.; PARK, K. J. Métodos de seleção de secadores. Food Science and Technology, v.25, p.208216, 2005. ISSN 0101-2061. Available from: <http:// www.scielo.br/scielo.php? script $=$ sci_arttext\&pid $=$ S010120612005000200004\&nrm=iso $>$. Accessed: Oct. 29, 2020. doi: 10.1590/S0101-20612005000200004.

BROOKER, D.Bet al. Drying and storage of grains and oilseeds. The AVI Publishing Company, Westport, Connecticut, USA, 1992.

CHIGURUPATI, $\mathrm{N}$ et al. Evaluation of red cabbage dye as a potential natural color for pharmaceutical use. International Journal of Pharmaceutics, v. 241, p. 293-299, 2002.

COSTA, Z. R. T et al. Mathematical models of banana drying kinetics (Musa ssp). Congresso Técnico Científico da Engenharia e da Agronomia - CONTECC'2018. 2018 Maceió/ AL, Brasil Available from: <https://www.confea.org.br/sites/ default/files/antigos/contecc2018/agronomia/157_mmdcdsdbms. pdf>. Accessed: Nov. 22, 2020.

CRANK, J. The Mathematics of Diffusion, 2nd ed. Oxford: Claredon Press, 1975.

GIUSTI, M. M., WROLSTAD, R. E. Characterization and measurement of anthocyanins by UV-visible spectroscopy. Current protocols in food analytical chemistry, v.00(v.1), F1.2.1-F1.2.1, 2001. doi: 10.1002/0471142913.faf0102s00.

GONELI, A. L. D.; et al. Cinética de secagem dos grãos de café descascados em camada delgada. Revista Brasileira de Armazenamento, Viçosa, n.11, p.64-73, 2009.

HENRÍQUEZ, C. et al. Kinetic modeling of phenolic compound degradation during drum-dryingof apple peel by-products. Journal of Food Engineering, v.143, p.146-153, 2014. Available from $<$ http://doi.org/:\%2010.1016/j.jfoodeng.2014.06.037>.

INSTITUTO ADOLFO LUTZ-IAL . Métodos Físico-Químicos para Análise de Alimentos. Brasília. IV Edição, 1018p, 2005.

ISHIGURO, K et al. Comparison of anthocyanin and polyphenolics in purple sweet potato (Ipomoea batatas L.) grown in different locations in Japan. Preprints, 2017. Available from: <https:// www.preprints.org/manuscript/201712.0176/v1>. Accessed: Oct. 29, 2020. doi: 10.20944/preprints201712.0176.v1. 
JIANTENG, $\mathrm{XU}$ et al. Characterisation and stability of anthocyanins in purple-fleshed sweet potato P40. Food Chemistry, v.186, p.90-96, 2015.

KIM, H. W. et al. Anthocyanin changes in the Korean purplefleshed sweet potato, Shinzami, as affected by steaming and baking. Food Chemistry, v.130, n.4, p.966-972, 2012. Available from: <https://www.sciencedirect.com/science/article/abs/pii/ S0308814611011630>. Accessed: Oct. 29, 2020. doi: 10.1016/j. foodchem.2011.08.031

MADAMBA, P. S. et al.. The thin-layer drying characteristics of garlic slices. Journal of Food Engineering, v.29, n.1, p.75-97, 1996. doi: 10.1016/0260-8774(95)00062-3.

NASCIMENTO, C. M. O. Propriedades físico-químicas, nutricionais e funcionais de farinha de batata doce de polpa alaranjada e seu potencial de coloração de Petit Suisse 2017. 58p. Dissertação (Mestrado em Ciência e Tecnologia de Alimentos) - Instituto de Tecnologia, Departamento de Tecnologia de Alimentos, Universidade Federal Rural do Rio de Janeiro.

OLIVEIRA, $\mathrm{H}$ et al. Comparison of the in vitro gastrointestinal bioavailability of acylated and non-acylated anthocyanins: Purplefleshed sweet potato vs red wine. Food Chemistry, v.276, p.410 418, 2019. Available from: <https://www.sciencedirect.com/ science/article/abs/pii/S0308814618317448>. Accessed: Oct. 29, 2020. doi: 10.1016/j.foodchem.2018.09.159.

OLIVEIRA, K. K. G. et al.. Efeito do calor sobre a estabilidade das antocianinas purificadas do resíduo agroindustrial de uva cv. Isabel. In: anais do simpósio latino americano de ciências de alimentos, 2015,Anais eletrônicos. Campinas, Galoá, 2015. Available from $<$ https://proceedings.science/slaca/slaca-2015/papers/efeitodo-calor-sobre-a-estabilidade-das-antocianinas-purificadas-doresiduo-agroindustrial-de-uva-cv--isabel?lang=pt-br $>$. Accessed: Oct. 29,2020

PARK, K. J et al. Estudo de secagem de pera bartlett (Pyrus sp.) em fatias. Food Science and Technology, v. 21, p. 288-292, 2001. Available from: <http://www.scielo.br/scielo.php?script $=\mathrm{sci}$ arttext\&pid=S0101-20612001000300007\&nrm $=$ iso $>$ Accessed: oct. 29, 2020. doi: 10.1590/S0101-20612001000300007.

PARK, K. J., et al. Conceitos de processo e equipamentos de secagem. CTEA, Unicamp. 2007. Available from: <http://www. feagri.unicamp.br/ctea/projpesq.html>

PILON, L., et al. Avaliação físico-química e compostos bioativos de farinhas de batatas-doces de polpa roxa. Brasília: EMBRAPA, 2020. (Boletim de pesquisa e desenvolvimento 202).

RODRIGUEZ-SAONA, L. E. et al. Anthocyanin pigment composition of red-fleshed potatoes. Journal of Food Science v.63, n.3, p.458-465, 1998

ROESLER, P. V. S. et al. Produção e qualidade de raiz tuberosa de cultivares de batata-doce no oeste do Paraná. Acta Science Agronômica, v.30, n.1, p.117-122, 2008. Available from: $<$ https:// www.scielo.br/scielo.php?script $=$ sci_abstract\&pid $=\mathrm{S} 1807$ $86212008000100017 \& \operatorname{lng}=$ pt\&nrm $=$ iso $\&$ tlng $=$ pt $>$. Accessed Oct. 29, 2020. doi: 10.4025/actasciagron.v30i1.1159.

RUFINO, M. DO S. M. et al. Bioactive compounds and antioxidant capacities of 18 non-traditional tropical fruits from Brazil. Food Chemistry, v. 121, n. 4, p. 996-1002, 2010. Available from:
$<$ https://ainfo.cnptia.embrapa.br/digital/bitstream/item/34191/1/ PA10008.pdf>. Accessed: Oct. 29, 2020. doi: 10.1016/j. foodchem.2010.01.037.

SAPERS, G.M et al. Functional properties of a food colorant prepared from red cabbage. Journal of Food Science, v.46, p.105$109,1981$.

SILVA, L.M.M et al. Experimental study of achachairu pulp of drying in thin layer. Gaia scientia, v.9 n.1, p.151-155, 2015. Available from: <https://periodicos.ufpb.br/ojs2/index.php/gaia/ article/download/18136/14849>. Accessed: Oct. 29, 2020.

SWAIN, T.; HILLIS, W. E. The phenolic constituents of Prunus domestica I.- The quantitative analysis of phenolic constituents. Journal of Science and Food Agriculture, Washington, v.10, p.63-68, 1959.

TANG, Y. et al. Profiles of phenolics, carotenoids, and antioxidative capacities of thermal processed white, yellow, orange and purple sweet potatoes grown in Guilin, China. Food Science and Human Wellness, v.4, p.123-132, 2015. Available from: <https://www. sciencedirect.com/science/article/pii/S2213453015000427>. doi: 10.1016/j.fshw.2015.07.003.

TAVONE, L. S. et al. Comparison of mathematical models of banana pão/sapo drying kinetics in green maturation stage. Brazilian Journal of Development, v.6, n.6, p.35611-35622,2020. Available from: <https:// www.brazilianjournals.com/index.php/BRJD/article/view/11350/9473>. Accessed: Oct. 30, 2020. doi: 10.34117/bjdv6n6-194.

TEOW, C. Cet al. Antioxidant activities, phenolic and $\beta$ - carotene contents of sweet potato genotypes with varying flesh colours. Food Chemistry, 103, 829-838, 2007. Available from: <https:// www.ars.usda.gov/ARSUserFiles/60701000/Sweetpotato $\% 20$ Publications/S121.pdf>. doi: 10.1016/j.foodchem.2006.09.033.

TOYAMA, J. et al. Selection of sweet potato lines with high protein content and/or low trypsin inhibitor activity. Breeding Science, v.56, p.17-23, 2006. Available from: < https://www.jstage.jst.go.jp/ article/jsbbs/56/1/56_1_17/_pdf $>$. Accessed: Oct. 29, 2020. doi: $10.1270 /$ jsbbs. 56.17 .

TRUONG, V.-D. et al. Characterization of anthocyanins and anthocyanidins in purple fleshed sweet potatoes by HPLC-DAD/ ESI-MS/MS. Journal of Agricultural and Food Chemistry, v.58, n.1, 404 410, 2010. Available from: <https://pubmed.ncbi.nlm.nih. gov/20017481/>. Accessed: Oct. 29, 2020. doi: 10.1021/jf902799a.

VIZZOTTO, M. et al. Physicochemical and antioxidant capacity analysis of colored sweet potato genotypes: in natura and thermally processed. Ciência Rural, v.47, 2017. Available from: $\quad<$ https://www.scielo.br/scielo.php?script=sci arttext\&pi $\mathrm{d}=\mathrm{S} 0103-84782017000400751>$. Accessed: Oct. 29, 2020. doi: $10.1590 / 0103-8478 \mathrm{cr} 20151385$

YANG, J. et al.. Effects drying processes on the antioxidan properties in sweet potatoes. Agricultural Sciences in China, v.9, n.10, p 1522-1529, 2010. Available from: <https://www. sciencedirect.com/science/article/abs/pii/S1671292709602467>. doi: 10.1016/S1671-2927(09)60246-7.

ZHU, F. et al. Anthocyanins, hydroxycinnamic acid derivatives, and antioxidant activity in roots of different Chinese purple fleshed sweet potato genotypes. Journal of Agricultural and Food Chemistry, v.58 n.13, p.7588-7596, 2010. Available from: $<$ https://pubmed.ncbi.nlm.nih. gov/20524661/>. Accessed: Oct. 29, 2020. doi: 10.1021/jf101867t 